Article

\title{
Innovative System for Heat Recovery and Combustion Gas Cleaning
}

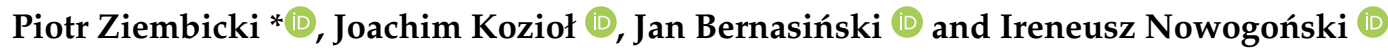 \\ Faculty of Civil Engineering, Architecture and Environmental Engineering, University of Zielona Góra, \\ Prof. Z. Szafrana 15 St., 65-516 Zielona Góra, Poland; kojo643@interia.pl (J.K.); jan.bernasinski@gmail.com (J.B.); \\ i.nowogonski@iis.uz.zgora.pl (I.N.) \\ * Correspondence: p.ziembicki@iis.uz.zgora.pl
}

Received: 27 September 2019; Accepted: 5 November 2019; Published: date

\begin{abstract}
The Polish as well as the global energy economy, including in particular heat generation, is to a great extent based on facilities for the combustion of liquid and gaseous fuels. Globally, a considerable part, and in Poland a vast majority of these facilities are much worn out, and, consequently, they work with low efficiency producing considerable amounts of pollutants, which have a very negative impact on the environment. Therefore, it is of crucial importance to develop innovative solutions that enhance the efficiency of fuel combustion and at the same time reduce emission of pollutants. The paper presents a solution which renders it possible to increase the efficiency of fuel conversion by heating up substrates of combustion processes, heat recovery from combustion gases as a result of their cooling and water vapor condensation and which contributes to a reduction of pollution. The solution brings about significant fuel consumption savings and thus a considerable enhancement of economic and ecological efficiency of heat sources is achieved. The solution is specially dedicated to heat sources of low and medium power. The technology developed and described herein will also allow an elimination of environmental burdens caused by inefficient heat sources already in operation.
\end{abstract}

Keywords: heat recovery; combustion gas cleaning; energy efficiency; fuel combustion

\section{Introduction}

The demand for heat for heating purposes and preparation of domestic hot water is to a significant extent covered by the use of installations which burn gaseous and liquid fuels. A significant part of these systems in the EU [1], and most of them in Poland [2], are extremely worn-out. They are not efficient and produce considerable amounts of impurities and pollutants which have a negative effect on the environment [3]. In his publication [4], Lombardi stated that the existing technologies related to heat recovery from waste treatment technological systems do not implement any solutions related to the removal of pollution from exhaust gases, but only the recovery of heat from waste. In addition, heat recovery efficiency remains at relatively low levels. In the review of solutions for technological systems of heat sources made in the publication [5], Barma described the applied methods of heat recovery, including from exhaust gases. However, he did not describe a technological system that, in addition to being a recuperator, would also make the removal of pollutants from exhaust gases possible. The author additionally stated in the publication that, in addition to the use of typical recuperator solutions, other solutions should also be sought, e.g., to increase the temperature of combustion substrates, as well as to recover heat of condensation. Barma did not indicate specific solutions to this problem. The device implementing such processes has been proposed by the authors of this publication. There are many solutions available on the market that are intended for recovering heat from combustion gases. However, these solution are frequently characterized by small energy efficiency. They only function as 
heat exchangers. They do not reduce emission of pollutants generated by technological systems of heat sources. They include various types of recuperators, i.e., heat exchangers, which recover waste heat, for example from combustion gases. Solutions with recuperators can include devices installed as separate elements of the technological system of the heat source or devices which constitute an integral part of the combustion chamber, e.g., in condensing boilers. In his publication [6], Blanco described an interesting heating solution that allows the heating of air supplied to the combustion chamber. However, the main purpose of the described device is to analyze the impact of acid dew point temperature (ADT) on the operation of a boiler powered by different types of fuel. The author did not refer to the increase of boiler efficiency, let alone to the reduction of the amount of emitted flue gas. In their publication [7], Yang et al. focused on a new heat recuperator solution that aims to recover heat from exhaust gases. The interesting solution proposed by the authors of [7] is radically different from the device developed by the authors of this manuscript, mainly in the scope of additional possibilities of purifying exhaust gas, as well as water recovery from exhaust gas. The power ranges of the energy sources for which both devices are dedicated are significantly different. Similar solutions to Yang's, but dedicated to smaller heat sources, were proposed by Liu [8] and Chen [9].

Recently, systems with compressor or sorption heat pumps for the recovery and reuse of waste heat have been used most frequently. In their publications, Zhu [10] and Qu [11] proposed a completely different approach to the issue of heat recovery from boiler flue gas. They used absorption heat pumps for this purpose. These are completely different solutions from the device proposed by the authors of this manuscript. The coefficient of efficiency of heat recovery, the lack of the possibility of simultaneous flue gas cleaning, and high market prices of sorption heat pumps cause that their use as devices improving the efficiency of heat sources remains debatable. An interesting concept of using an adsorption heat pump for reusing the heat generated by a district heating system in the summer period, when the heat is treated as waste heat, was discussed by Ziembicki et al. [12]. However, the solutions for heat recovery with the use of recuperators and/or heat pumps do not in any way affect changes in the combustion gas composition, thus they do not contribute to the reduction of environmental burden caused by heat sources. This is a serious disadvantage of these solutions in comparison to the installation described herein, which enhances energy efficiency of boilers and reduces emission of pollutants and impurities, including solid impurities.

Methods of improving control systems in heating boilers are also often applied in order to enhance energy efficiency of heat sources. In his work [13], Suntivarakorn presented a method of controlling the amount of fuel supplied to the combustion chamber by means of fuzzy control algorithms. The proposed solution allowed increasing the boiler efficiency by $4.34 \%$. Most often, they consist in improving combustion quality by controlling the air-to-fuel ratio. In contrast to the device described herein, these methods do not bring about a considerable reduction in pollutant emissions. Moreover, artificial neural networks, which are often implemented in controllers, need learning processes based on complex algorithms as well as learning data. This has a negative effect on the costs and time required for the modernization of control systems. Analyses of the use of genetic algorithms, artificial neural networks and deep learning methods were presented by Pan [14], Chen [15] and Cheng [16].

Combustion of oils in boilers is possible when the oils are converted to gaseous state and heated to ignition temperature. The main factors which affect the combustion process and emission of the resultant pollutants are: the composition of the fuel (hydrocarbon composition, the content of sulfur, incombustible minerals and solid impurities, and the content and type of fuel oil conditioners and modifiers) and the construction of the burner and combustion chamber. The advancement in the construction of boilers and burners has affected significantly a reduction in emission of pollutants; however, the emission of soot and unburned hydrocarbons mostly during the start-up and shut-down of a boiler remains a problem. At the time of start-up and shut-down, $50-70 \%$ of soot is generated with adsorbed products of the polymerization of hydrocarbons and unburned 
hydrocarbons [17]. Combustion of poor quality fuel oils, e.g., light oil with an addition of heavy oil, constitutes another problem.

Based on extensive literature review in the field of the already existing solutions for heat recovery and exhaust gas purification, it was found that currently there are no market solutions that would simultaneously carry out these two tasks in the way proposed in the developed system. Technical systems which are intended only for heat recovery are relatively widespread. It should be emphasized that the developed system is significantly different from solutions available on the market, as well as from those that are currently in the research phase and whose preliminary operational results are described in the available scientific publications. This difference mainly concerns simultaneous heat recovery and flue gas cleaning, as well as increased efficiency of heat recovery.

Heavy fuel oils have a greater content of sulfur and other mineral substances, which in the process of combustion create together with water vapor aggressive compounds that have a corrosive impact on the combustion chamber (low-temperature corrosion). Moreover, they pollute the natural environment much more. In the combustion process, the compounds of iron, calcium, sodium and vanadium contained in the oil produce oxides, which at high temperature cause high-temperature corrosion. The content of high-molecular organic compounds, including heavy paraffin and tar compounds, is increased in contaminated light oil. In chambers which are not adjusted for such an oil, its combustion causes enhanced emission of soot and unburned hydrocarbons.

The requirements concerning pollutant emission to the atmosphere, those already in force as well as planned, make it necessary to use not only fuels of appropriate quality and more and more efficient construction of devices, but also necessitate development of solutions for combustion gas cleaning.

To characterize the developed solution in detail, this publication is divided into four sections. In the Introduction, a detailed overview of the current state of relevant knowledge is presented. Innovative aspects of the solution proposed by the authors are also presented, which constitute progress in the analyzed field and at the same time significantly differ in favor of the developed system as compared to those currently operating on the market and being put to tests by other authors. In Section 2, the authors present technical specifications of the proposed system. They describe the structure and the functioning of the device, as well as detailed diagrams of the system. The initial paragraphs of this section feature some literature references to solutions and methods that were used during the research, which were significantly improved in the developed system. Section 3 describes the results of theoretical analyses of the developed solution and is partly based on selected measurements from the previous version of the solution. Section 4 contains conclusions regarding research and analysis of the developed system, as well as plans for its potential development and further research and testing.

\section{Materials and Methods}

\subsection{Combustion Gas Cleaning and Heat Recovery from Combustion of Liquid Fuels}

Light fuel oil is most frequently burned in oil boiler-rooms of small and medium power. Medium and heavy fuel oil is occasionally used for heating purposes in production facilities, e.g., in horticulture. In terms of the volume of production of vegetable oils in the world, rapeseed oil comes second after soya oil. The EU countries are its largest producers. In these countries, rapeseed oil is most frequently used for heating purposes [1]. Oils for heating are characterized by high viscosity, high surface tension and difficult ignition (it is a mixture of fractions boiling in a wide range of temperatures) and therefore it is burned blended with fuel oil [18].

The greatest advancement in new constructions is observed in industrial fuel oil burners, which, in comparison with burners of small and medium power, are characterized by very high emission of pollutants. An example would be the burner design developed by Ling [19] or the solution proposed by Liu [20]. Systems of automatic control and adjustment of air flow to the boiler, which are used in modern boilers, allow maintaining energy efficiency at a relatively high level. Oil condensing boilers 
(of the power of approximately up to $350 \mathrm{~kW}$ ) also enhance the energy efficiency of liquid fuel boilers. In larger boilers, heat recuperators-flue-to-water heat exchangers-are installed in the exhaust system. Agarwal [21] and Barma [5] presented a broad review of the proposed solutions. During burning of light oils fuel oil conditioners, so-called combustion modifiers are also used. They lower the emission of toxic compounds (reduce the emission of unburned and partly burned hydrocarbons and soot) and prevent collection of carbon deposits on the burner nozzles and in the combustion chamber [22]. These combustion modifiers are fed into the combustion chamber mainly in the form of a loose material or an emulsion. On the basis of the literature quoted herein, it can only be stated that modifiers are fed mainly to the combustion chamber and that there is a very wide range of catalytic agents (chemical elements and their compounds) and their carriers in common use. For example, modifiers based on magnesium oxides are dosed in the form of a suspension in oil or are dispergated in oil by means of surface-active agents. These oxides are also fed to the combustion chamber in the form of water-based suspension [23]. Many solutions for using combustion modifiers and also methods for reducing pollution by combustion gas cleaning have been described in the literature. However, they refer mainly to the combustion of fuel in combustion engines [24].

The speed of the combustion reaction grows together with temperature and the level of substrate fragmentation. Oil viscosity and surface tension, which diminish with an increase in temperature, are the parameters which decide about the degree of fuel atomization. For instance, heating up to the temperature from $20-50{ }^{\circ} \mathrm{C}$ lowers the viscosity of fuel oil by about $50 \%$, whereas in the case of rapeseed oil-by approximately $30 \%$ [25]. This helps achieving a better atomization of droplets after they are discharged from the burner nozzle and obtaining an appropriate outflow cone for a given construction of a furnace. Droplets of sprayed oil evaporate and are transformed into hydrocarbon gas. The mixture thus created, when it reaches the right temperature, gets ignited and forms the flame front.

Burners in boilers are calibrated for fuel oil of particular viscosity. When the viscosity is higher, less fuel will be fed to the combustion chamber and this will result in a higher chimney loss because the amount of air pumped to the chamber is also calibrated. At the same time, it will hinder proper fuel atomization and its effective, complete combustion. In the event of too low viscosity, more fuel will be pumped to the combustion chamber and it will not be completely combusted as the amount of air is calibrated. If the amount of fuel pumped to the combustion chamber is decreased, it will not be possible to obtain a proper pressure on the burner's nozzle and fuel atomization will deteriorate. It follows from the technical data provided by various manufacturers of burners that, for light fuel oils, the range of admissible changes in fuel viscosity should not exceed about $1 \mathrm{cSt}$. The ignition temperature of rapeseed oil is closely connected with its evaporation capacity. Rapeseed oil is a mixture of fractions which boil in a wide range of temperatures. Compared to fuel oil, it is characterized by a high ignition temperature. A significant reduction of this temperature can be obtained by mixing rapeseed oil with light fuel oil (addition of $10 \%$ by weight reduces the ignition temperature by approximately $50 \%$ ) [25]. The temperature in the space between the burner nozzle outlet and the flame front should be lower than the fuel cracking temperature in both phases (liquid and gaseous). If the cracking process takes place in the liquid phase, carbon in the form of coke is precipitated, whereas, in the gaseous phase, soot is produced, on the surface of which hydrocarbons produced in the flame are deposited. The higher are the amount and size of emitted particles of soot, the worse is the atomization of fuel. In the case of liquid fuel combustion, more than 150 different hydrocarbons have been identified in combustion gases [26]. Highly carcinogenic compounds (fluorene, pyrene, benzopyrene, etc.), which are comprised in the soot, deeply penetrate the respiratory system of living organisms.

The effect of condensation of water vapor contained in combustion gases is known and has been used in condensing boilers since 1894 [27]. However, it should be underlined that typical processes aiming at optimization of the performance of boilers for combusting liquid fluids cover only heat recovery, and to a much lesser extent they focus on heat recovery combined with combustion gas cleaning. Examples of solutions are included in literature reviews by Patterson [28], Johuary [29] and Varga [30]. It should be emphasized that none the solutions and methods described in the above 
publications combine the improvement of energy efficiency of the heat source with simultaneous removal of pollutants from exhaust gases, which is a feature of the system developed by the authors of this manuscript. One example is a device and method for the recovery of heat and dry cleaning of combustion gases that consists in using a non-membrane heat and mass exchanger, in which water from condensation of water vapor contained in combustion gases gets cooled in a membrane exchanger situated outside the device, and then is circulated to remove dust and gaseous compounds from combustion gases [31,32]. The heat transferred to the water cooling agent in the external heat exchanger defines the recovery of heat, which (apart from cleaning the combustion gases) is the main objective. From the patent number [33], there is also known a device for saving liquid fuel, in which the air for combustion is heated by combustion gases initially in an exchanger situated outside the chimney of the installation, with a simultaneous condensation of water vapor contained in them. Then, air is heated in a membrane exchanger by means of circulating water obtained from water vapor condensation. Combustion gases are cleaned in mechanical filters with metal or plastic packed beds and in water mist which is obtained by spraying the circulating water.

\subsection{Innovative System for Heat Recovery and Combustion Gas Cleaning}

The solution which was developed and is discussed herein comprises an installation for fuel saving, combustion gas cleaning and recovery of heat and water from combustion gases produced in combustion chambers of boilers, industrial furnaces, combustion engines, gas turbines, reaction chambers, etc., which use liquid or gaseous fuel, mainly biofuels. It is particularly dedicated to devices of small and medium power, in which technologically advanced methods of combustion gas cleaning are not used. As a result of fuel combustion in combustion chambers, combustion gases of high temperature are produced, which are used to obtain a useful effect. Before combustion gases are released to the atmosphere, they may be of a relatively high temperature, which is a measure of the effect of sensible heat. They also contain water vapor which is the source of latent heat. Such combustion gases should be used for the generation of secondary useful effects, e.g., external heating of energy carriers and/or heating of substrates of the combustion process, i.e., air and/or fuel. It follows from the information published in the literature (e.g., [34]) that the use of combustion gases flowing out of the combustion chamber for heating of combustion substrates achieves a particularly high energy, economic and ecological efficiency. A diagram of the installation is shown in Figures 1 and 2, where the elements of the installation are numbered as follows:

1. second stage combustion gas-air exchanger;

2. sprinkler;

3. first stage combustion gas-air exchanger;

4. condensation track;

5. combustion gas-fuel exchanger;

6. separator;

7. combustion gas tunnel;

8. combustion gas fan;

9. water tank;

10. sedimentation tank;

11. water pump;

12. pipes;

13. control valves;

14. air fan; and

15. fuel pump.

Combustion gases from the chamber flow through a cross-flow pipe heat exchanger, used in the second air heating stage, and then they are directed to the condensation tract for condensing water 
vapor contained in combustion gases. The tract is made up of the following pieces of equipment: a sprinkler and two cross-flow heat exchangers used for the first stage of fuel and air heating. It also serves as an absorber and washer for combustion gas cleaning.

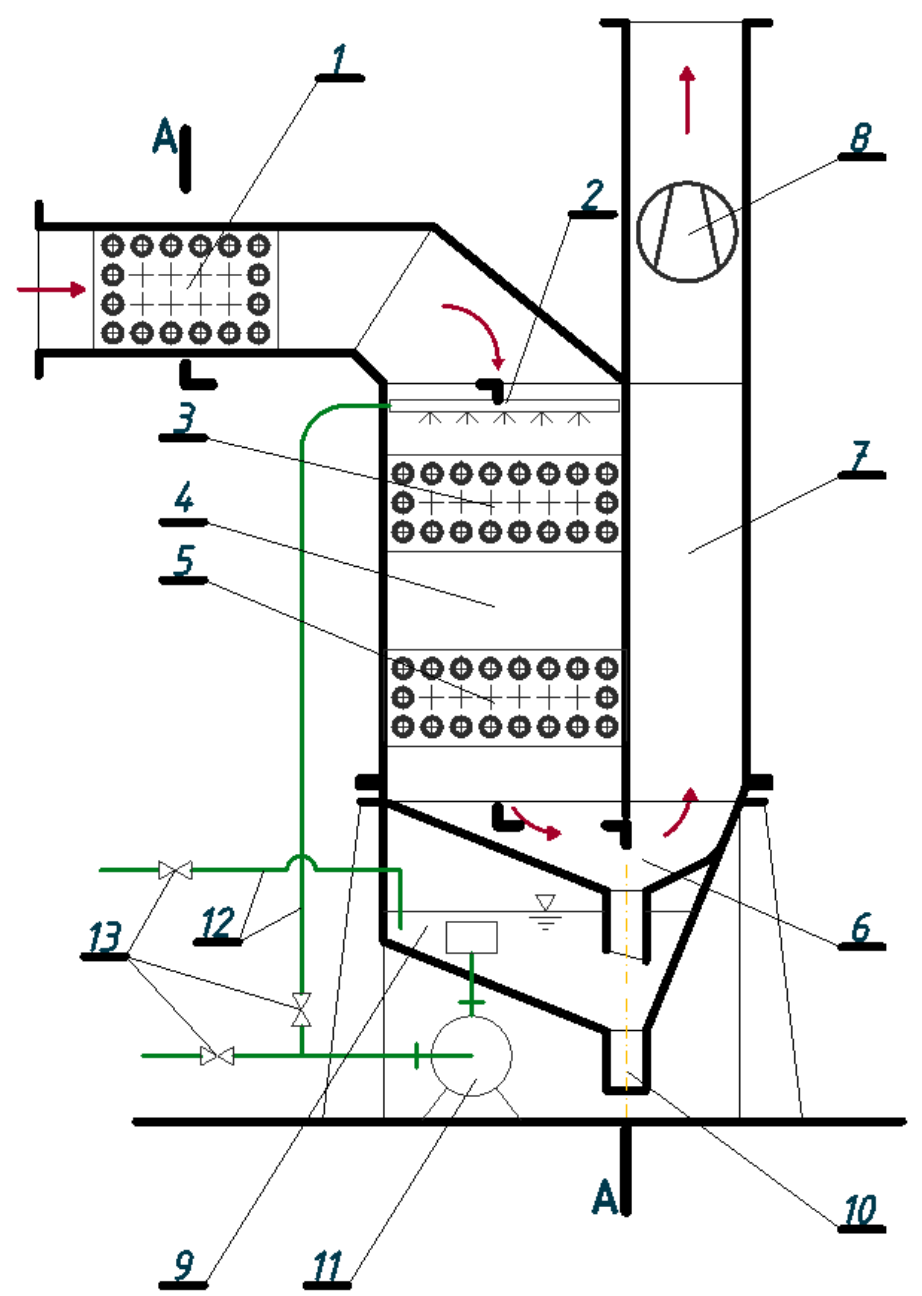

Figure 1. A diagram of the installation for fuel savings, combustion gas cleaning and heat and water recovery from combustion gases produced in combustion chambers.

Then, combustion gases flow through a separator to a combustion tunnel from which they are discharged to a chimney by a fan. After heating, air and fuel are pumped to a burner. Circulating water atomized in a sprinkler and the condensate together with combustion gases flow to the separator and through a blowdown connection flow off to a sedimentation tank. By means of a pump-pipeline system and control valves, water from the tank is directed to the system of heat recovery and the sprinkler for the purpose of regulating the temperature of combustion gases and intensifying the processes of water vapor condensation, absorption and removal of solid impurities. The installation is a modular structure and, depending on the requirements of the combustion process, it can be modified, i.e., two-stage heating can be performed only for the air or both for the fuel and air at the same time. Clean air and fuel flow through the space of heat exchanger pipes, and therefore the necessity of its in-service cleaning is eliminated. Thus, it is possible, for instance, to build-in some elements which increase the turbulence of flowing fluids and the heat transfer coefficient to the pipes' surfaces. The space in between the pipes through which only combustion gases or combustion gases and sprayed water flow is an open space, which is easy to be cleaned. The modular structure of the installation also facilitates an easy disassembly of its elements and, moreover, it renders it possible to use the space between heat exchangers in the condensation tract as pall rings in order to increase the 
area of contact between the gaseous and liquid phase, thus to enhance the efficiency of removal and absorption of impurities.

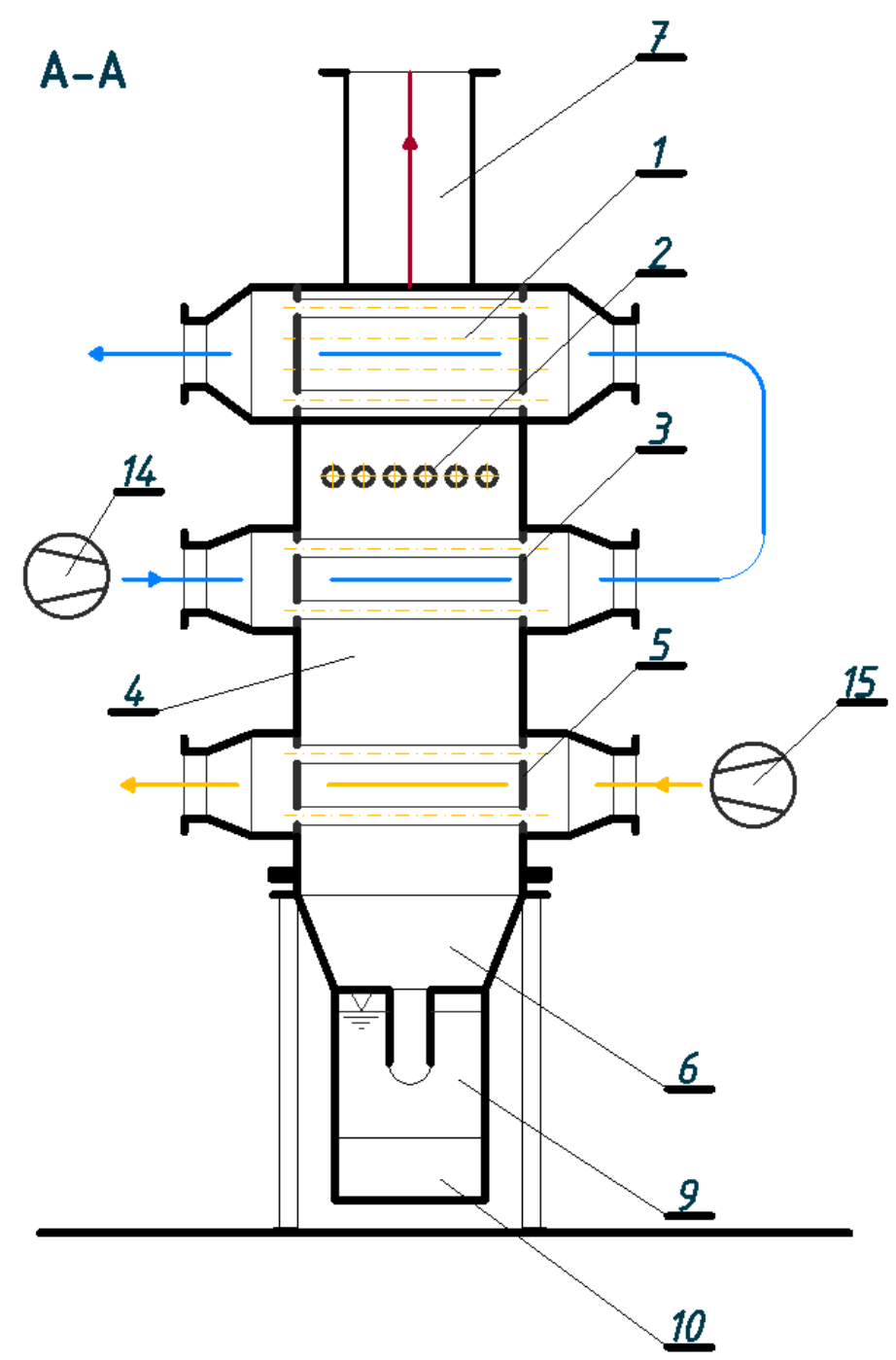

Figure 2. A diagram of the installation for fuel savings, combustion gas cleaning and heat and water recovery from combustion gases produced in combustion chambers-cross-section A-A (markings as in Figure 1).

Depending on the kind and quality of fuel, savings up to $10 \%$ can be achieved [35]. It is tantamount to the high economic and ecological efficiency. The installation can cooperate with combustion chambers supplied with a conventional liquid or gaseous fuel and with a biofuel. It can also be used for combustion gas cleaning without preliminary dust collectors, especially filters. The drawback of the solution is the necessity of keeping the installation tight. Moreover, elements of the installation should be made of acid-proof materials, e.g., acid-proof steel. The acid reaction $(\mathrm{pH}=2-5)$ and a relatively high temperature of the circulating water $\left(40-45^{\circ} \mathrm{C}\right)$ make it necessary to use acid-proof materials.

The installation can also be manufactured using non-metal materials, for example teflon. These materials, however, have very unfavorable thermal conductivity coefficients and therefore their usability in constructing heat exchangers is relatively small. An improvement in the thermal conductivity of a material, while keeping a high resistance to aggressive factors and a low flow resistance, can be achieved by applying protective coatings $50-200 \mu \mathrm{m}$ in thickness put on elements made of, for example, boiler steel. The assumptions presented above concerning fuel savings resulted from the assessment of operation of a previously built installation having similar constructional 
features, on the basis of which the device described in this article was developed. The installation was used at the Euro-Box company for heating the air for drying motorcycle frames, which were spray painted. The analytical relations presented in the article constitute the basis for the automatic control of the air-fuel ratio and the assessment of fuel recuperative heating. Further tests of the installation presented in the paper have been planned under a new research and implementation project. However, the project has not been implemented yet due to lack of funding.

\section{Results and Discussion}

An efficient way of using fuel consists in restricting the emission of waste energy and reducing its adverse environmental effects. The above-mentioned objectives can be achieved by means of introducing specific changes in the construction of devices and by optimizing their performance. The most important activities pertaining to optimization of the performance include control of the air-fuel ratio and selection of its proper values. Stoichiometry of the combustion process was analyzed extensively by J.Szargut [34]. The correctness of the combustion process can be checked by measuring the composition of combustion gases. To this aim, we should measure $\mathrm{CO}_{2}, \mathrm{O}_{2}, \mathrm{CO}$ and $\mathrm{H}_{2} \mathrm{O}$ content in the wet combustion gases. The following relation holds for the content of the $i$ th component in the dry and wet combustion gases:

$$
(i)=\frac{[i]}{1+X}
$$

where $(i),[i]$ are the content of the $i$ th component in the wet and dry combustion gases. $X$ is the content of $\mathrm{H}_{2} \mathrm{O}$ in the wet combustion gases-the so-called moisture level of combustion gases. It should be borne in mind that the content of combustion gas components is always determined or measured with a certain error. On the basis of the generalized Ostwald triangle, the intended composition can be adjusted [34]. The adjustment consists in correcting the measured contents of combustion gas components (mainly oxygen and carbon dioxide) in such a way that, using the smallest possible correction, they would satisfy the conditions which follow from the stoichiometry of the combustion process. The adjusted content of carbon dioxide $\left[\mathrm{CO}_{2}\right]_{\mathrm{ad}}$ and oxygen $\left[\mathrm{O}_{2}\right]_{\mathrm{ad}}$ may be calculated by using the formulae:

$$
\begin{aligned}
{\left[\mathrm{CO}_{2}\right]_{\mathrm{ad}} } & =\frac{A B}{A^{2}+B^{2}}\left(1-\left[\mathrm{CO}_{2}\right]+\frac{A}{B}\left[\mathrm{O}_{2}\right]\right) \\
{\left[\mathrm{O}_{2}\right]_{\mathrm{ad}} } & =\frac{A B}{A^{2}+B^{2}}\left(1-\left[\mathrm{O}_{2}\right]+\frac{A}{B}\left[\mathrm{CO}_{2}\right]\right)
\end{aligned}
$$

and

$$
\begin{gathered}
A=\mathrm{k}_{\max }\left(1-\frac{[\mathrm{CO}]}{1_{\max }}\right) \\
B=0.21\left(1-\frac{[\mathrm{CO}]}{1_{\max }}\right)
\end{gathered}
$$

where $\left[\mathrm{O}_{2}\right],\left[\mathrm{CO}_{2}\right]$, and $[\mathrm{CO}]$ are the content of oxygen, carbon dioxide and carbon monoxide before adjustment, respectively; $\left[\mathrm{O}_{2}\right]_{\mathrm{ad}}$ and $\left[\mathrm{CO}_{2}\right]_{\mathrm{ad}}$ are the content of oxygen and carbon dioxide after adjustment, respectively; and $\mathrm{k}_{\max }$ and $\mathrm{l}_{\max }$ are the maximum theoretical content of $\left[\mathrm{CO}_{2}\right]$ and $[\mathrm{CO}]$ in the dry combustion gases, respectively - the coefficient depends on the type of fuel. Usually, contents of $\left[\mathrm{CO}_{2}\right]$ and $[\mathrm{CO}]$ are not adjusted. All values used in Equations (2), (3), (4), (5) and (6) are absolute values. The content of $\left[\mathrm{H}_{2} \mathrm{O}\right]$ in wet combustion gases is used to recalculate the content of components in wet combustion gases into an analogical content in dry combustion gases (Equation (1)). Then, the problem with determining $\left[\mathrm{H}_{2} \mathrm{O}\right]$ does not occur. When some probes for measuring combustion gas components are used, the results can be directly related to dry combustion gases. Calculations were made for light fuel oil in order to determine the impact of uncertainty of $\left[\mathrm{H}_{2} \mathrm{O}\right]$ determination on the uncertainty of the air-fuel ratio $\lambda$ determination. When the uncertainty of $\left[\mathrm{H}_{2} \mathrm{O}\right]$ determination is changed by $6 \%$, the uncertainty of $\lambda$ is $0.5 \%$. This justifies the simplifications made by the authors, 
which consist in not adjusting the measured values of $[\mathrm{CO}]$ and $\left[\mathrm{H}_{2} \mathrm{O}\right]$. The values of maximum contents of $k_{\max }$ and $l_{\max }$ are given in Table 1 [36]. $k_{\max }$ and $l_{\max }$ are dimensionless quantities.

Table 1. Indicative maximum values of theoretical contents of carbon dioxide and carbon monoxide for the fuels used in the installation.

\begin{tabular}{ccc}
\hline Type of Fuel & $\mathrm{l}_{\max }$ & $\mathrm{k}_{\max }$ \\
\hline Light fuel oil & 0.157 & 0.223 \\
\hline Heavy fuel oil & 0.160 & 0.229 \\
\hline Natural gas & 0.115 & 0.147 \\
\hline
\end{tabular}

In a general case, the air-fuel ratio is determined from the balance of the following elements after a prior determination of the theoretical air demand: $\mathrm{C}, \mathrm{H}, \mathrm{O}$, and $\mathrm{N}$. In the case of combustion of fuels containing little nitrogen and when at the same time there is no free carbon in solid combustion products, the following formula can be used to determine the air-fuel ratio $\lambda$ [34]:

$$
\lambda=\frac{1}{1-\frac{79}{21} \frac{\left[\mathrm{O}_{2}\right]_{\mathrm{ad}}-\frac{1}{2}[\mathrm{CO}]}{1-\left[\mathrm{CO}_{2}\right]_{a d}-\left[\mathrm{O}_{2}\right]_{\mathrm{ad}}}-[\mathrm{CO}]}
$$

The above relation is particularly suitable, because it does not require knowledge of fuel composition. When the combustion chamber is supplied with fuel oil or natural gas, it is recommended to keep $\lambda=1.1-1.2$. A favorable and effective manner to enhance the energy, ecological and economic efficiency of the combustion chamber is to heat the substrates of combustion (air and/or fuel) with the heat which is recovered through recuperation. Recuperation brings additional energy to the chamber and increases the temperature of fuel combustion. This makes it possible, among other things:

- to intensify the use of combustion gases in the chamber;

- to save fuel;

- to obtain a higher content of $\mathrm{H}_{2} \mathrm{O}$ in combustion gases (e.g., in driers) and $\mathrm{CO}_{2}$ (in technological processes); and

- $\quad$ to lower the temperature of combustion gases discharged to the environment.

Fuel savings due to recuperation is defined by the index [37]:

$$
\omega=\frac{\Delta P}{P_{0}}=\frac{\chi q_{r}}{W_{d}+\chi q_{r}-S \Delta T_{S O}}
$$

where $\Delta P$ is fuel savings; $P_{0}$ is fuel consumption without recuperation; $W_{d}$ is fuel calorific value; $S$ is heat capacity of combustion gases per fuel unit; $q_{r}$ is heat of recuperation in relation to fuel unit; $\Delta T_{S O}$ is difference between the temperature of combustion gases flowing out of the chamber without a recuperator and the ambient temperature; and $\chi$ is index of temperature distribution.

$$
q_{r}=A \Delta T_{a}+B \Delta T_{b}
$$

where $A$ and $B$ are air and fuel heat capacity per fuel unit, respectively. $\Delta T_{a}$ and $\Delta T_{b}$ are difference between the temperature of heated air and fuel and the ambient temperature, respectively. $\Delta P$ and $P_{0}$ are expressed in commonly used fuel units. $W_{d}$ and $q_{r}$ are expressed in $\mathrm{KJ} /$ fuel unit. $A, B$, and $S$ are expressed in $\mathrm{KJ} /($ fuel unit $\cdot \mathrm{K}) . \omega$ and $\chi$ are dimensionless quantities. $\Delta T_{S O}, \Delta T_{a}$, and $\Delta T_{b}$ are expressed in $\mathrm{K}$. It is recommended to adopt the indices of temperature distribution in the combustion chamber in the following ranges [38]:

- $\quad$ for a one-zone chamber $\chi=1-1.15$; 
- for a counter-current flow of combustion gases and heated medium in the chamber $\chi=1.1-1.3$; and

- for a multi-zone chamber $\chi=1.3-1.5$.

After the combustion gases are cooled below the dew point, the water vapor contained in them is successively condensed. Condensation brings about an intensive heat transfer to the condensing agent. The water droplets which appear not only absorb gaseous impurities contained in combustion gases, but also remove solid impurities from them. The process of water vapor condensation in combustion gases should be treated as particularly favorable for making use of combustion gas waste heat and combustion gas cleaning.

The research did not include the recovery and reuse of condensed water from flue gases. This is an issue that should be considered in future research.

The proposed solution is associated with increased capital expenditures and higher operating costs compared to classic (familiar) solutions. The increase in the above costs will, according to estimated analyses, be offset by the positive effects associated with fuel economy and the qualitative and quantitative improvement of pollutant emissions. An estimated analysis of simple payback time for the development and implementation of the solution was carried out. As mentioned above, for financial reasons, no prototype of the installation described in the publication was built. However, a similar construction had been built (the previous version of the device) and, based on the analysis of this solution, simple payback time was estimated. The cost of installation of a similar design (in the previous version of the device) for a $160 \mathrm{~kW}$ boiler amounted to approximately 7100 Euro. According to the operational data on the average boiler load operating in the system $(120 \mathrm{~kW})$, its operation time per year, reduction in oil consumption (compared to the boiler without the device) and fuel cost, simple payback time was estimated. It was 2.6 years for the analyzed parameters.

The results of theoretical analyses of the developed solution, as well as the analyses of selected operating results of the previous version of the system are extremely encouraging. Especially in the areas of increased efficiency of heat recovery, as well as within the aspect of ecological benefits consisting in the reduction of pollutants emitted to the atmosphere. The developed system can be particularly useful for small and medium energy sources, as an element of their technological systems which significantly improves the economic effects of heat production, while reducing its burden on the environment. This is particularly important in the context of adverse climate change of anthropogenic origin. To optimize the production costs of the device, future research should be carried out, which would take into account modern materials devoid of expensive stainless steel and would also reduce the dimensions of the device. In addition, tests should be carried out that will make it possible to extend the functionality of the device in order to recover water condensed from exhaust gases, which can further significantly increase the economic efficiency of the developed device. Conditions that will allow the system to be introduced on the market constitute an extremely important aspect that should be considered in subsequent work on the system. In particular, precise specifications of cost framework for the production of the device, including various power ranges of the heat source (boilers) with which the system will function optimally from the point of view of economic and ecological efficiency.

\section{Conclusions}

An efficient use of fuel requires control of the air-to-fuel ratio and selection of its optimal values. Heating up the substrates of combustion in the process of recuperation and condensation brings additional energy to the combustion chamber and results in increasing the temperature of combustion gases in the combustion chamber. This in turn enhances the efficiency of the process. In addition, condensation of the water vapor contained in combustion gases reduces the emission of substances harmful to the environment, mainly by washing out solid impurities.

The invention presented herein is comprised of an installation that uses combustion gases for heating combustion substrates, recovers heat by condensing water vapor contained in combustion gases and cleans them in the process of absorption and removal of solid impurities. Liquid or gaseous fuel and air are heated in membrane heat exchangers that fill up the absorption column acting also as a 
washer, in which gaseous and solid impurities are absorbed and removed by water. Air and/or fuel is additionally heated in an exchanger placed at the combustion gas inlet to the installation. The solution is characterized by a simple construction and a high energy efficiency. In addition, it can be modified for individual needs for fuel and air heating by using multi-section exchangers and two-stage heating of combustion substrates.

The development of the device described in the paper is a consequence of earlier tests and research work on a solution based on identical assumptions and theoretical fundamentals; however, the device under consideration here was built using a slightly different construction (technology). The results of the tests proved to be so promising that the Board of Euro-Box commissioned development of a new generation of the device. The company intended to install the device on other production floors and considered its prospective distribution on a commercial basis. An application under the Regional Operational Programme in the Lubuskie administrative province was filed for financial aid for testing the device which was developed and its implementation. Financial analyses, including the concept of implementation and commercialization, also proved to be extremely promising. This means that there is a great potential for implementing the device (of various sizes and power). The prospects look bright, especially when we take into account the current state of industrial enterprises in Poland, where quite frequently, due to their location (lack of gas networks), worn-out liquid fuel boilers and/or devices supplied with biogas are still in operation.

\section{Patents}

A patent application for the invention was filed to the Patent Office of the Republic of Poland [39].

Author Contributions: Conceptualization, P.Z. and J.B.; methodology, J.K.; software, I.N.; validation, P.Z., J.B. and J.K.; visualization, I.N.; and supervision, P.Z.

Conflicts of Interest: The authors declare no conflict of interest.

\section{References}

1. IEA. Weo 2017; World Energy Outlook; OECD: Paris, France, 2017; pp. 33-61.

2. Wojdyga, K.; Chorzelski, M. Chances for Polish district heating systems. Energy Procedia 2017, 116, $106-118$. [CrossRef]

3. Ziemele, J.; Cilinskis, E.; Blumberga, D. Pathway and restriction in district heating systems development towards 4th generation district heating. Energy 2018, 152, 108-118. [CrossRef]

4. Lombardi, L.; Carnevale, E.; Corti, A. A review of technologies and performances of thermal treatment systems for energy recovery from waste. Waste Manag. 2015, 37, 26-44. [CrossRef] [PubMed]

5. Barma, M.C.; Saidur, R.; Rahman, S.M.; Allouhi, A.; Akash, B.A.; Sait, S.M. A review on boilers energy use, energy savings, and emissions reductions. Renew. Sustain. Energy Rev. 2017, 79, 970-983. [CrossRef]

6. Blanco, J.M.; Peña, F. Increase in the boiler's performance in terms of the acid dew point temperature: Environmental advantages of replacing fuels. Appl. Therm. Eng. 2008, 28, 777-784. [CrossRef]

7. Yang, Y.; Xu, C.; Xu, G.; Han, Y.; Fang, Y.; Zhang, D. A new conceptual cold-end design of boilers for coal-fired power plants with waste heat recovery. Energy Convers. Manag. 2015, 89, 137-146. [CrossRef]

8. Liu, L.; Fu, L.; Jiang, Y. Application of an exhaust heat recovery system for domestic hot water. Energy 2010, 35, 1476-1481. [CrossRef]

9. Chen, Q.; Finney, K.; Li, H.; Zhang, X.; Zhou, J.; Sharifi, V.; Swithenbank, J. Condensing boiler applications in the process industry. Appl. Energy 2012, 89, 30-36. [CrossRef]

10. Zhu, K.; Xia, J.; Xie, X.; Jiang, Y. Total heat recovery of gas boiler by absorption heat pump and direct-contact heat exchanger. Appl. Therm. Eng. 2014, 71, 213-218. [CrossRef]

11. Qu, M.; Abdelaziz, O.; Yin, $\mathrm{H}$. New configurations of a heat recovery absorption heat pump integrated with a natural gas boiler for boiler efficiency improvement. Energy Convers. Manag. 2014, 87, 175-184. [CrossRef]

12. Ziembicki, P.; Bernasiński, J.; Kozioł, J. The production of chilled water from a low-temperature medium of district heating systems. In Proceedings of the 32nd International Conference on Efficiency, Cost, Optimization, Simulation and Environmental Impact of Energy Systems, Wrocław, Poland, 23-28 June 2019. 
13. Suntivarakorn, R.; Treedet, W. Improvement of Boiler's Efficiency Using Heat Recovery and Automatic Combustion Control System. Energy Procedia 2016, 100, 193-197. [CrossRef]

14. Pan, H.; Zhong, W.; Wang, Z.; Wang, G. Optimization of industrial boiler combustion control system based on genetic algorithm. Comput. Electr. Eng. 2018, 70, 987-997. [CrossRef]

15. Chen, X.; Gao, L.; Zhou, J.; Gao, H.; Wang, L.; Wang, X.; Chen, B. Boiler combustion control model of large-scale coal-fired power plant with asymmetric artificial neural networks. In Proceedings of the 2017 IEEE 2nd Information Technology, Networking, Electronic and Automation Control Conference (ITNEC), Chengdu, China, 15-17 December 2017.

16. Cheng, Y.; Huang, Y.; Pang, B.; Zhang, W. ThermalNet: A deep reinforcement learning-based combustion optimization system for coal-fired boiler. Eng. Appl. Artif. Intell. 2018, 74, 303-311. [CrossRef]

17. Junblut, H.; Horning, M.; Lohman, G.; Herne. J. Optimirung von Heizoelfeuerungsanlagen durch Additives. Technische Arbeitstagung. Mineraloeltechnik 1997, 42, 1-24.

18. Codina Gironès, V.; Moret, S.; Peduzzi, E.; Nasato, M.; Maréchal, F. Optimal use of biomass in large-scale energy systems: Insights for energy policy. Energy 2017, 137, 789-797. [CrossRef]

19. Ling, Z.; Zhou, H.; Ren, T. Effect of the flue gas recirculation supply location on the heavy oil combustion and NOx emission characteristics within a pilot furnace fired by a swirl burner. Energy 2015, 91, 110-116. [CrossRef]

20. Liu, H.; Chaney, J.; Li, J.; Sun, C. Control of NOx emissions of a domestic/small-scale biomass pellet boiler by air staging. Fuel 2013, 103, 792-798. [CrossRef]

21. Agarwal, S.; Suhane, A. Study of Boiler Maintenance for Enhanced Reliability of System A Review. Mater. Today Proc. 2017, 4, 1542-1549. [CrossRef]

22. Guziałowska-Tic, J.; Tic, W.J. Analysis of the adverse impact of an iron-based combustion modifier for liquid fuels on human health. J. Clean. Prod. 2018, 174, 1527-1533. [CrossRef]

23. Poullikkas, A. Cost-benefit analysis for the use of additives in heavy fuel oil fired boilers. Energy Convers. Manag. 2004, 45, 1725-1734. [CrossRef]

24. Romero, C.E.; Li, Y.; Bilirgen, H.; Sarunac, N.; Levy, E.K. Modification of boiler operating conditions for mercury emissions reductions in coal-fired utility boilers. Fuel 2006, 85, 204-212. [CrossRef]

25. Altin, R.; Çetinkaya, S.; Yücesu, H.S. Potential of using vegetable oil fuels as fuel for diesel engines. Energy Convers. Manag. 2001, 42, 529-538. [CrossRef]

26. Łomankiewicz, D.; Brodzik, K.; Bielczyc, P. Identyfikacja metoda̧ GC-MS związków w spalinach z zapłonem iskrowym zasilanych paliwem z dodatkiem biometanolu. Logistyka 2015, 3, 2901-2910.

27. Weber, C.; Gebhardt, B.; Fahl, U. Market transformation for energy efficient technologies-Success factors and empirical evidence for gas condensinng boilers. Energy 2002, 27, 287-315. [CrossRef]

28. Persson, U.; Münster, M. Current and future prospects for heat recovery from waste in European district heating systems: A literature and data review. Energy 2016, 110, 116-128. [CrossRef]

29. Jouhara, H.; Khordehgah, N.; Almahmoud, S.; Delpech, B.; Chauhan, A.; Tassou, S.A. Waste heat recovery technologies and applications. Therm. Sci. Eng. Prog. 2018, 6, 268-289. [CrossRef]

30. Varga, Z.; Palotai, B. Comparison of low temperature waste heat recovery methods. Energy 2017, 137, 1286-1292. [CrossRef]

31. Ostrowski, P.; Pronobis, M.; Gramatyka, F.; Olewiński, H.; Habram, T. Sposób oraz Instalacja Odzysku Ciepła i Mokrego Oczyszczania Niskotemperaturowych Spalin Odprowadzanych do Otoczenia, Zwłaszcza Komór Spalania. Patent. 2010. Avaliable online: https://grab.uprp.pl/PrzedmiotyChronione/Strony\% 20witryny/Wyszukiwanie\%20proste.aspx (accessed on 1 August 2019).

32. Ostrowski, P.; Pronobis, M.; Gramatyka, F.; Hausner, J.; Kalisz, S.; Ostrowski, Z.; Wejkowski, R. Sposób Intensyfikacji Wykorzystania Ciepła Odzyskanego w Układach Schładzania Niskotemperaturowych Spalin Odprowadzanych do Otoczenia. Patent. 2015. Avaliable online: https://grab.uprp.pl/ PrzedmiotyChronione/Strony\%20witryny/Wyszukiwanie\%20proste.aspx (accessed on 1 August 2019).

33. Kreikler, W. Device for Creation of e.g. Temperature Changes in Old and/or New Oil-Fired Boilers, Has Exhaust Gas Ventilators Producing Low Pressure, and Burner Whose Nozzle Holder Is Heated with Hot Water or Cold Water. Patent. 2013. Avaliable online: https:/ / pl.espacenet.com/ (accessed on 1 August 2019).

34. Szargut, J. Termodynamika techniczna; Wydawnictwo Politechniki Śląskiej: Gliwice, Poland, 1991; pp. 64-75.

35. Kozioł, J.; Tkocz, M. Odzysk energii odpadowej oraz wody ze spalin odpływających z kotła elektrociepłowni. III Konferencja Naukowo-Techniczna “Współczesne Technologie i Urządzenia Energetyczne”, Cracow, 
Poland. 16 November 2013. Avaliable online: http:/ / www.bg.polsl.pl/expertus/view/exprec.php?term= 0000089693 (accessed on 1 August 2019).

36. Szargut, J.; Ziębik, A.; Kozioł, J.; Inni, I. Racjonalizacja użytkowania energii w zakładach przemysłowych; FPE: Warszawa, Poland, 1994.

37. Szargut, J.; Andrzej, Z. Podstawy Energetyki Cieplnej; Wydawnictwo Naukowo-Techniczne: Warszawa, Poland, 2000. (In Polish)

38. Szargut, J.; Koziol, J. Influence of the temperature distribution in the furnace chamber on the effects of recuperation. Gaswaerme Int. 1990, 39, 180-184.

39. Kozioł, J.; Ziembicki, P.; Bernasiński, J. Sposób i Instalacja do Oszczȩdzania Paliwa, Oczyszczania Spalin Oraz Odzysku Wody ze Spalin w Komorach Spalania. Patent. 2015. Avaliable online: https://grab.uprp.pl/ PrzedmiotyChronione/Strony\%20witryny/Wyszukiwanie\%20proste.aspx (accessed on 1 August 2019).

(C) 2019 by the authors. Licensee MDPI, Basel, Switzerland. This article is an open access article distributed under the terms and conditions of the Creative Commons Attribution (CC BY) license (http://creativecommons.org/licenses/by/4.0/). 